\title{
PENELITIAN EFISIENSI ENERGI PADA MESIN HORIZONTAL BORING \& MILLING
}

\author{
Sony Harbintoro \\ Balai Besar Logam dan Mesin \\ Kementerian Perindustrian \\ J1. Sangkuriang 12 Bandung - Jawa Barat \\ Email: sonystrada@yahoo.com
}

\begin{abstract}
ABSTRAK
Penelitian mengenai efisiensi energi pada mesin horizontal boring \& milling telah dilaksanakan di workshop pemesinan Metal Industries Development Center Bandung. Efisiensi energi pada bidang manufaktur merupakan salah satu faktor penting dalam proses mendukung green industry. Penelitian ini menganalisa dampak dari retrofit sistem kendali terhadap penggunaan energi listrik pada mesin horizontal boring \& milling. Metode penelitian efisiensi penggunaan daya listrik dilaksanakan sebelum dan sesudah retrofit pada sistem kendali. Pengukuran penggunaan daya listrik dilaksanakan pada saat mesin mengerjakan benda kerja dengan material yang sama. Data dari hasil pengukuran, dianalisis untuk mendapatkan besaran efisiensi energi listrik. Dari penelitian ini ditampilkan bahwa setelah dilakukan retrofit sistem kendali, dapat dicapai penurunan penggunaan energi listrik sebesar $21,5 \%$.
\end{abstract}

Kata Kunci: sistem kendali, efisiensi, energi, horizontal boring \& milling

\section{ABSTRACT}

Research on energy efficiency in a horizontal boring and milling machine has been implemented in the machining workshop at Metal Industries Development Center Bandung. Energy efficiency in the manufacturing process is one of the important factors to support the green industry. This research analyzed the impact of the control system retrofit on the horizontal boring and milling machine for the electric energy consumption. The methods of research was conducted before and after the retrofit of the control system. Measurements was carried out on the use of electrical power was using the same workpiece material. Data from the experiment was analyzed to obtain the amount of electrical energy efficiency. This research was shown that, after the control systems retrofit, the reduction about $21.5 \%$ of electrical energy can be achieved.

Keywords: control system, eficiency, energy, horizontal boring \& milling

\section{PENDAHULUAN}

Mesin horizontal boring \& milling merupakan salah satu mesin perkakas yang banyak digunakan dalam proses pemesinan benda kerja yang besar sehingga dibutuhkan energi listrik yang besar untuk menggerakan mesin tersebut. Kapasitas mesin horizontal boring \& milling dapat dilihat dari seberapa berat meja mesin tersebut mampu mengerjakan benda kerja dan seberapa besar diameter perkakas potong yang dapat dipasang pada quil spindle-nya.

Workshop pemesinan Metal Industries Development Center (MIDC) mempunyai satu unit mesin horizontal boring \& miiling dengan kapasitas meja mesin 3 ton benda kerja dan diameter spindle $90 \mathrm{~mm}$. Mesin tersebut merupakan mesin buatan tahun 1973 dengan menggunakan sistem kontrol yang tua sehingga mengakibatkan mesin tersebut menjadi boros energi. Untuk mendapatkan kinerja mesin yang tetap optimal namun pemakaian energi listrik menjadi lebih efisien, maka dilakukan retrofit sistem kontrol dengan menambahkan fitur-fitur teknologi baru pada sistem kontrol yang lama. Sistem retrofit yang dilakukan yaitu mengganti sistem kontrol motor-generator operated drives menjadi variabel speed DC drive. Pengambilan data penggunaan energi pada mesin ini dilakukan sebelum proses retrofit sistem kontrol pada tahun 2011 dan setelah dilakukan retrofit sistem kendali pada tahun 2013. Sasaran yang dicapai dari penelitian ini adalah didapatkan data penghematan energi listrik dari mesin horizontal boring \& milling di MIDC setelah dilakukan proses retrofit sistim kontrol/ sistim kendali. Hasil dari penelitian ini dapat 
digunakan untuk mengidentifikasi tingkat penggunaan konsumsi energi sebagai data menuju kearah konservasi energi.

\section{Studi Pustaka}

\section{Mesin Horizontal Boring \& Milling}

Mesin horizontal boring \& milling merupakan gabungan mesin boring dan mesin milling dengan konstruksi horizontal. Mesin horizontal boring \& milling merupakan salah satu mesin perkakas yang banyak digunakan dalam pengerjaan benda kerja berat seperti engine frames, steam engine cylinders, machine housing, dll. Benda kerja yang dapat dikerjakan pada mesin horizontal boring \& milling merupakan benda kerja yang spesifik yang tidak bisa dikerjakan pada mesin bubut atau mesin drilling. Dengan menggunakan alat bantu yang terdapat pada mesin itu, mesin ini dapat difungsikan sebagai mesin bubut, mesin drilling, face milling atau gear cutting ${ }^{(1)}$. Pada mesin horizontal boring \& milling, benda kerja ditempatkan pada meja sedangkan perkakas potong/tools berputar pada sumbu horizontal. Dengan tools yang sesuai, mesin dapat melakukan berbagai operasi pemesinan seperti boring, reaming, turning, threading, facing, milling dan grooving. Gambar 1 berikut ini menunjukkan mesin horizontal boring \& milling.

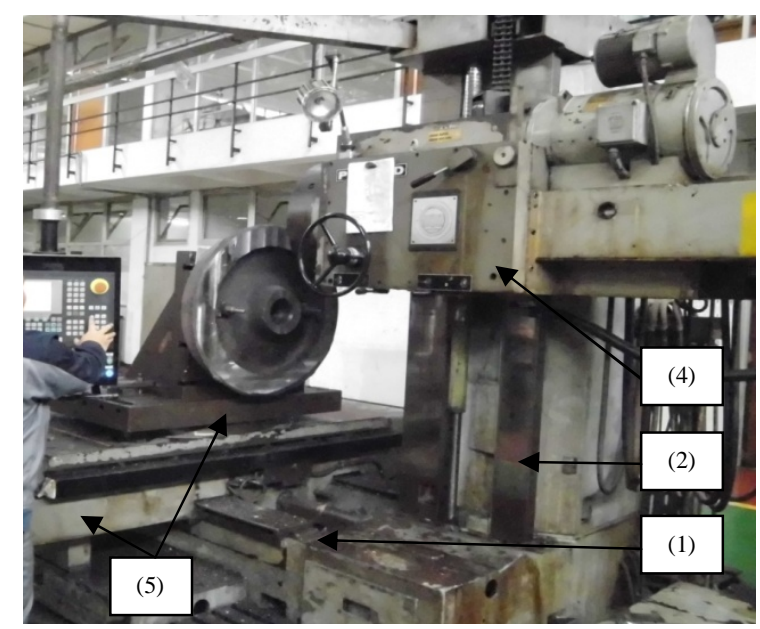

Gambar 1. Mesin horizontal boring \& milling

Tipe mesin horizontal boring \& milling dapat dikategorikan menjadi empat yaitu: (a) Table type, (b) Floor type (c), Planer type dan (d) Multiple head type. Bagian-bagian utama dari mesin horizontal boring \& milling antara lain:
(1) Bed: bed merupakan bagian dari mesin yang terpasang pada lantai workshop, fungsi bed yaitu menyangga columns, meja, dan bagian lainnya dari mesin.

(2) Headstock supporting column: bagian ini berfungsi menyangga headstocks dan menuntunnya dalam gerakan naik turun melalui guide ways pada column.

(3) End supporting column: bagian ini dipasang pada bed sebagai tumpuan boring bar, penempatan bagian ini dapat diatur mendekati atau menjauhi headstock tergantung pada seberapa panjang boring bar yang digunakan.

(4) Headstocks: bagian ini terletak pada column dan dapat bergerak naik-turun. Pada bagian ini terdapat spindle untuk memutar perkakas potong/tools sedangkan untuk melakukan operasi long drilling dapat digunakan quill yaang dapat bergerak longitudinal..$^{(1)}$

(5) Saddle dan table: table berfungsi untuk menempatkan benda kerja yang akan dikerjakan. Pada table terdapat T-slots untuk pemasangan baut pencekam benda kerja. Saddle merupakan bantalan/tumpuan yang mana table dapat bergerak transversal atau longitudinal, pergerakan table dilaksanakan dengan motor servo.

(6) Boring bars: bagian ini digunakan pada saat melakukan operasi memperbesar lubang/boring dengan diameter tools yang besar, sedangkan untuk melakukan operasi facing mill langsung dipasang pada taper spindle nose. ${ }^{(2)}$

Ukuran mesin horizontal boring \& milling ditentukan oleh seberapa besar diameter spindle $(\mathrm{mm})$, diameter spindle bervariasi dari 75 s.d. $355 \mathrm{~mm}$. Untuk spesifikasi yang lebih lengkap dapat dilihat dari seberapa besar daya motor spindle, tinggi columns, ukuran table, kecepatan putaran spindle, feeds dan panjang dari feeds, total luas lantai yang diperlukan, berat mesin dll.

Mekanisme mesin horizontal boring \& milling yaitu: (a) headstock dapat bergerak naik turun dengan digerakan oleh motor servo. (b) Spindle dapat memutarkan tools dengan kecepatan yang bervariasi digerakan oleh motor spindle. (c) Quill spindle dapat bergerak masuk atau keluar dengan digerakan manual atau motor servo. (d) Saddle dan table dapat digerakan arah longitudinal atau transversal dengan tenaga motor servo. Pada tabel 1 
ditampilkan harga kecepatan potong mesin horizontal boring \& milling Pegard.

Tabel 1. Kecepatan Potong : V (m/min)

\begin{tabular}{|l|c|c|c|c|}
\hline \multirow{2}{*}{$\begin{array}{c}\text { Material To } \\
\text { Be } \\
\text { Machined }\end{array}$} & \multicolumn{2}{|c|}{$\begin{array}{c}\text { High Speed Steel } \\
\text { Tools }\end{array}$} & \multicolumn{2}{c|}{ Carbide Tipped Tools } \\
\cline { 2 - 5 } & Roughing & Finishing & Roughing & Finishing \\
\hline Cast steel & 18 & 30 & 80 & 120 \\
\hline Cast Iron & 23 & 35 & 80 & 120 \\
\hline Steel 50 K & 35 & 50 & 100 & 220 \\
\hline Steel 70 K & 20 & 35 & 80 & 180 \\
\hline Bronze & 45 & 80 & 250 & 500 \\
\hline $\begin{array}{l}\text { Alumunium } \\
\text { Alloys }\end{array}$ & 65 & 100 & 150 & 400 \\
\hline
\end{tabular}

\section{Efisiensi Energi Mesin Perkakas}

Mesin perkakas dilengkapi dengan beberapa motor listrik dan komponen tambahan yang memerlukan konsumsi energi yang bervariasi selama proses pemesinan berlangsung. Energi listrik yang dibutuhkan pada saat proses milling yaitu diantaranya untuk sistim kontrol motor spindle dan motor pergerakan axis, motor pompa untuk pendingin pada saat pemakanan (coolant), unit pendingin oli hidrolik (oil cooler) dan komponen tambahan/aksesoris yang menggunakan energi listrik seperti lampu penerangan mesin dan ventilasi udara pada lemari sistem kontrol. ${ }^{(3)}$

\section{METODOLOGI}

\section{Benda kerja dan alat yang digunakan}

Benda kerja/objek yang digunakan untuk penelitian ini adalah mesin horizontal boring \& milling dengan kapasitas meja 3 ton, diameter spindle $90 \mathrm{~mm}$, buatan Belgia, tahun pembuatan 1973. (2) Sedangkan alat ukur yang digunakan pada penelitian ini yaitu volt meter digital, ampere meter, KWH meter, clamp meter, power meter dan tools set.

\section{Metode Penelitian}

Penelitian ini merupakan penelitian eksperimental dimulai dengan melakukan pengamatan karakteristik mesin horizontal boring \& milling dengan mempelajari manual book, dan penelitian sejenis yang telah dilakukan, melakukan pengambilan data awal pemakaian energi listrik pada mesin meliputi data tegangan (volt), besaran arus (ampere) dan daya listrik (watt), melakukan retrofit sistem kelistrikan dan sistem kendali, melakukan pengambilan data akhir, melakukan analisa data dengan membandingkan data pengukuran awal dan data pengukuran akhir serta menarik kesimpulan.

Berikut ini ditampilkan flow chart dari penelitian yang dilakukan:

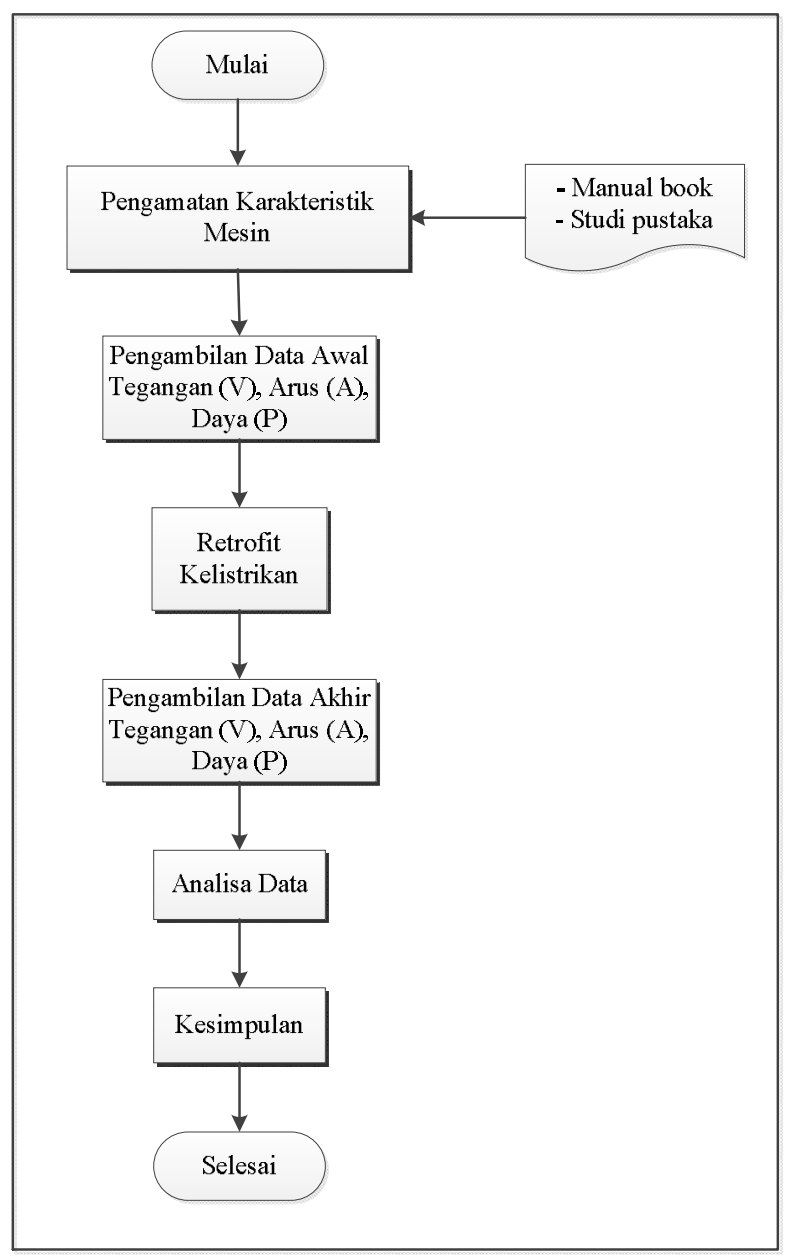

Gambar 2. Diagram alir penelitian yang dilakukan

\section{HASIL PENELITIAN}

Hasil pelaksanaan penelitian yang telah dilakukan terhadap mesin horizontal boring \& milling di workshop MIDC yaitu meneliti cara kerja sistem kelistrikan khususnya sistem kontrol pada motor spindle dan motor axis sebelum dan sesudah dilakukan retrofit. Bagian sistem kelistrikan motor spindle dan motor axis merupakan bagian yang paling besar penggunaan energi listriknya pada mesin tersebut. Sistem kontrol orisinil dari mesin horizontal boring \& milling ini yaitu menggunakan sistem motor-generator operated drives dimana masukan energi listrik tegangan AC 380 volt, 3 phase digunakan untuk menggerakan motor listrik yang dikopel dengan generator arus searah (DC), generator DC mengeluarkan tegangan listrik arus searah 
yang digunakan untuk menggerakan motor DC servo, untuk mengatur kecepatan motor DC servo digunakan rheostat/tahanan muka yang dapat diubah besaran tahanannya ${ }^{(2)}$. Berikut ini gambar dari sistem motor-generator operated drives.

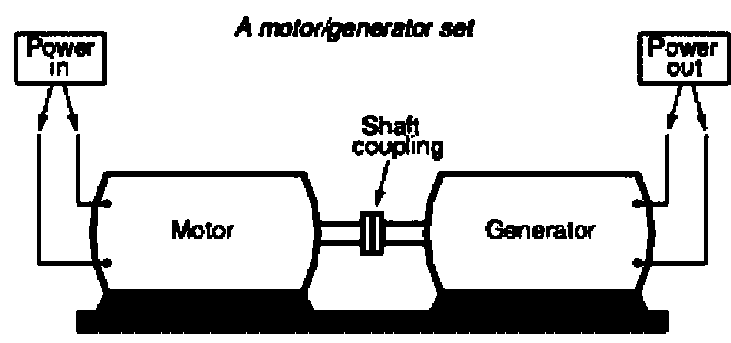

Gambar 3. Sistem motor-generator

Dari gambar 3, motor listrik akan berputar dikarenakan ada daya listrik yang masuk (power in), poros dari motor dihubungkan/dikopel dengan poros generator sehingga generator akan berputar dan menghasilkan daya listrik (power out).

Pada mesin horizontal boring dan milling ini terdapat dua generator DC yang difungsikan sebagai sumber tenaga listrik untuk motor spindle dan motor axis. Gambar 4 adalah sistem motor-generator untuk penggerak motor spindle.

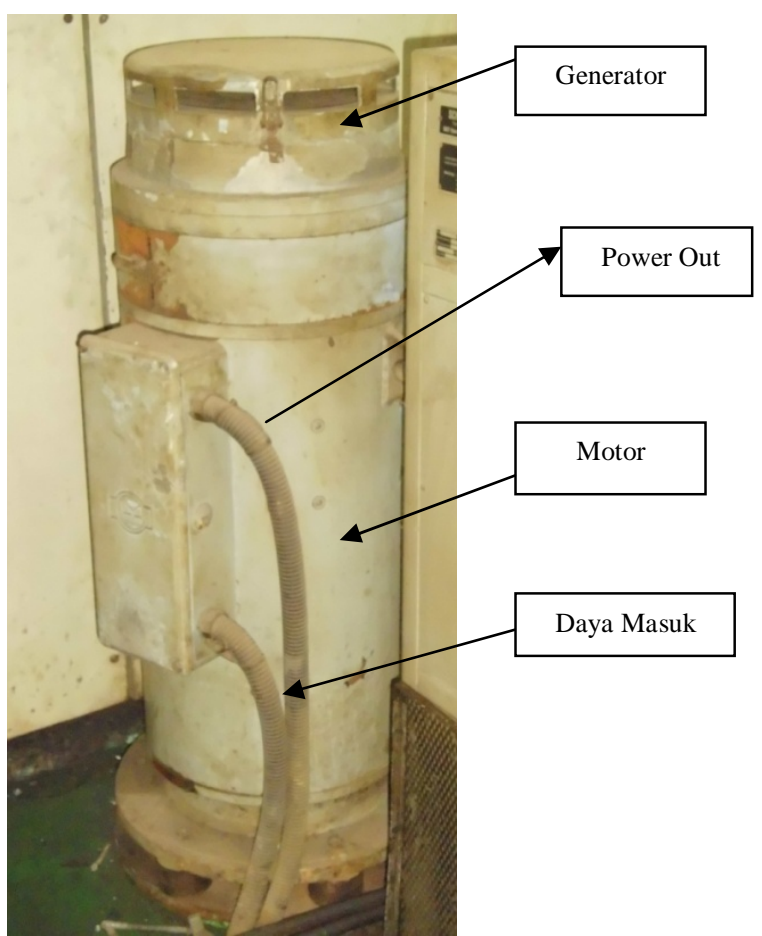

Gambar 4. Sistem motor-generator untuk penggerak motor spindle
Penggerak motor spindle menggunakan sistem motor - generator dengan kapasitas daya $15 \mathrm{KW}$, tegangan 380 volt, arus 28 ampere dan putaran nominal $2900 \mathrm{rpm}$ dengan tipe vertikal motor-generator coupled. Pengaturan kecepatan putaran motor spindle menggunakan dua cara yaitu (1) menggunakan variabel resistor yang diatur melalui panel kendali dan (2) secara manual menggunakan tuas pengatur transmisi roda gigi.

Motor axis terdiri atas dua motor servo yang disuplai dari satu set motorgenerator yang bekerja secara bergantian. Gambar motor-generator yang digunakan untuk penggerak motor axis pada gambar 5 di bawah ini.

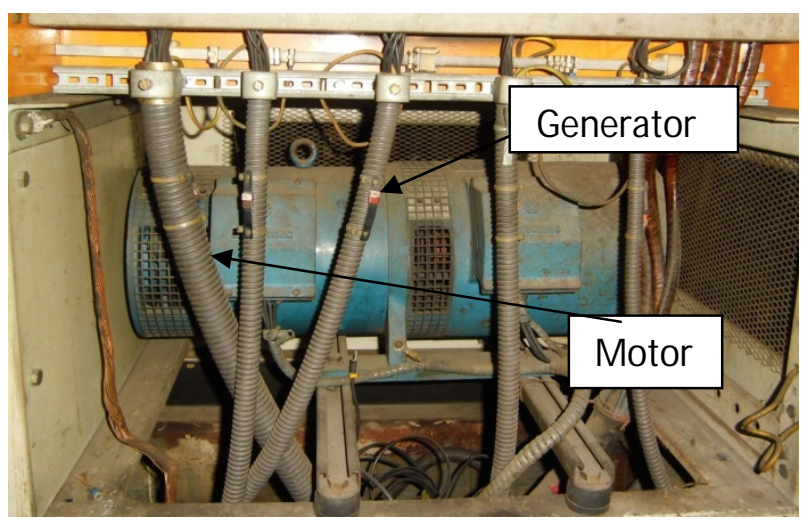

Gambar 5. Sistem motor-generator untuk penggerak motor axis

Sumber tenaga untuk motor axis didapat dari motor-generator dengan kapasitas $5 \mathrm{KW}$, tegangan 380 volt dan putaran 3470 rpm, untuk pengaturan kecepatan motor axis hanya menggunakan variabel resistor yang diatur melalui panel kendali. Motor axis hanya dapat dijalankan secara bergantian antara motor axis meja dan motor axis headstock dengan perantara magnetic coupling. Berikut ini ditampilkan skema diagram penggerak motor spindle dan motor axis. 


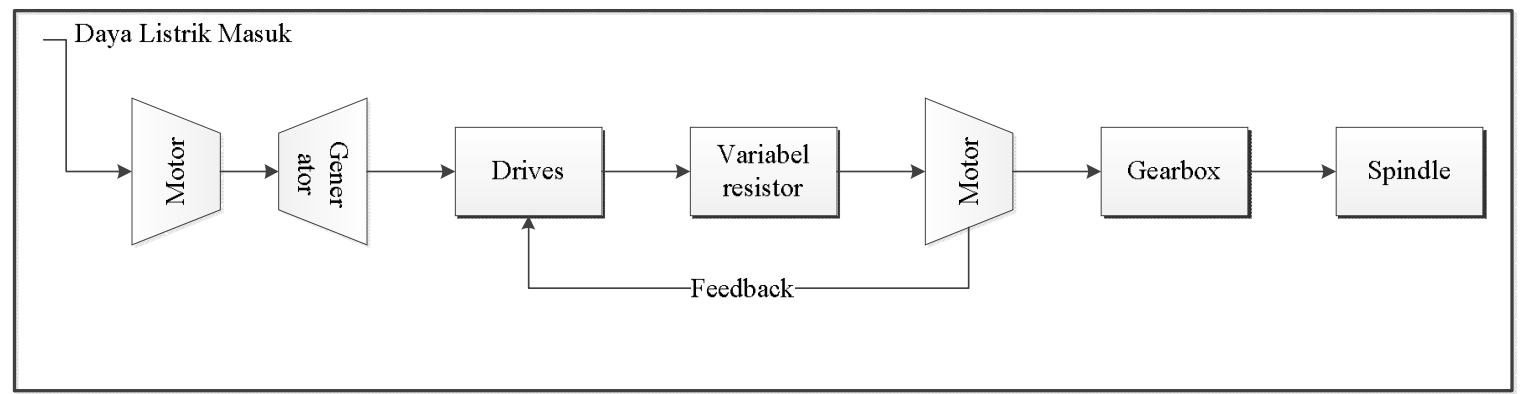

Gambar 6. Skema diagram penggerak motor spindle sebelum retrofit

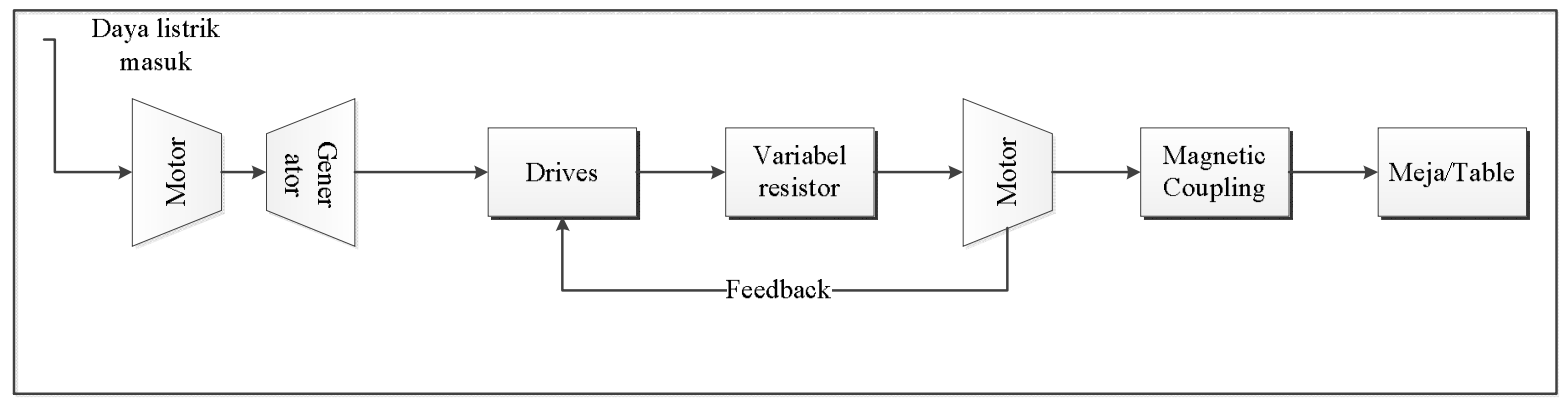

Gambar 7. Skema diagram penggerak motor axis sebelum retrofit

Pengambilan data dilakukan sebanyak enam kali untuk mengetahui penggunaan daya listrik pada mesin horizontal boring and milling sebelum dilakukan proses retrofit sistem kelistrikan khususnya pada sistem kendali didapat data sebagai berikut:

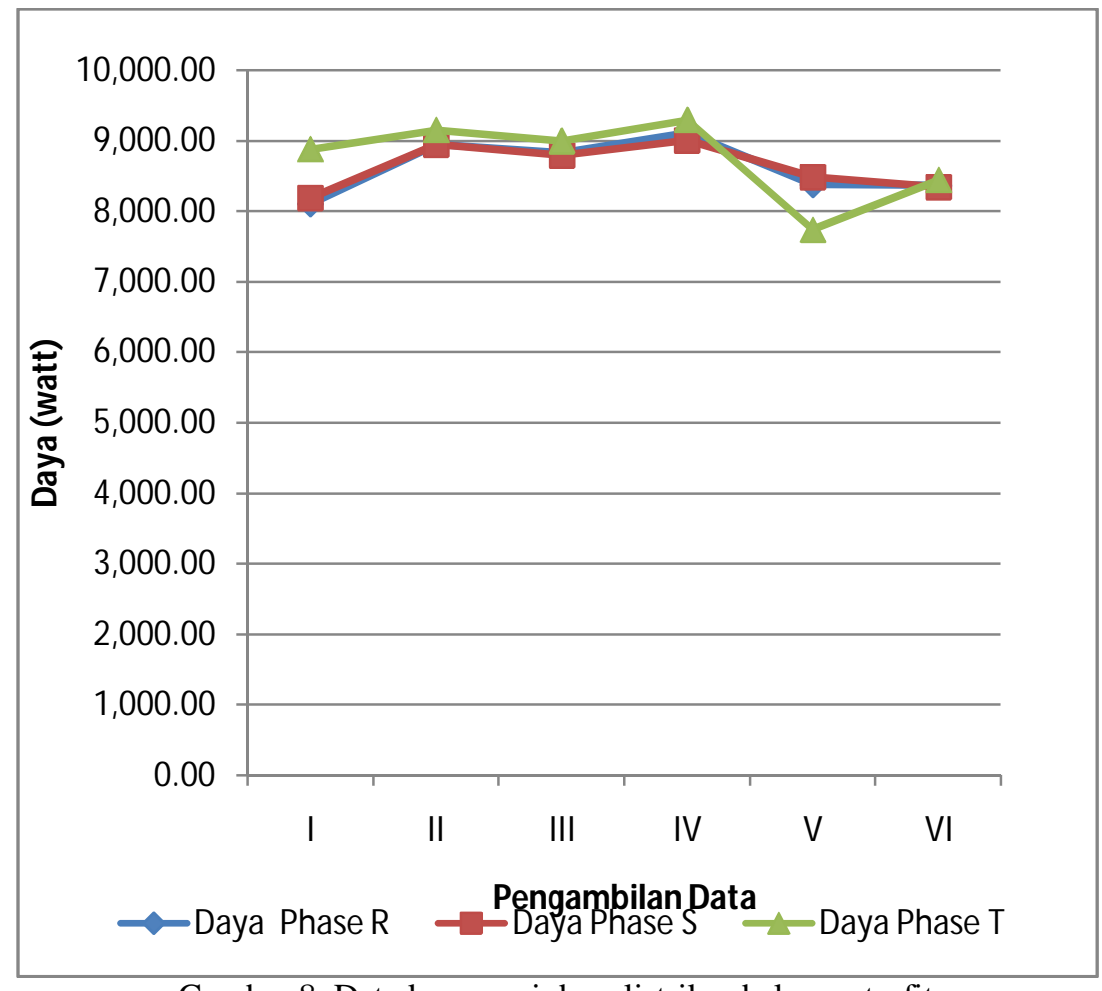

Gambar 8. Data konsumsi daya listrik sebelum retrofit 
Proses retrofit sistem kelistrikan dilakukan pada bagian sistem kendali motor spindle dan motor axis. Sistem kendali untuk motor spindle dan motor axis diubah dari sistem motor-generator operated drives menjadi sistem variabel speed DC drives ${ }^{(5)}$ sehingga sistem motor-generator set tidak lagi digunakan, namun tetap menggunakan motor DC servo yang lama (existing). Setelah dilakukan proses retrofit sistem kelistrikan khususnya pada bagian sistem kendali motor spindle dan motor axis maka skema diagramnya dapat dilihat pada gambar 9 dan 10 di bawah ini.

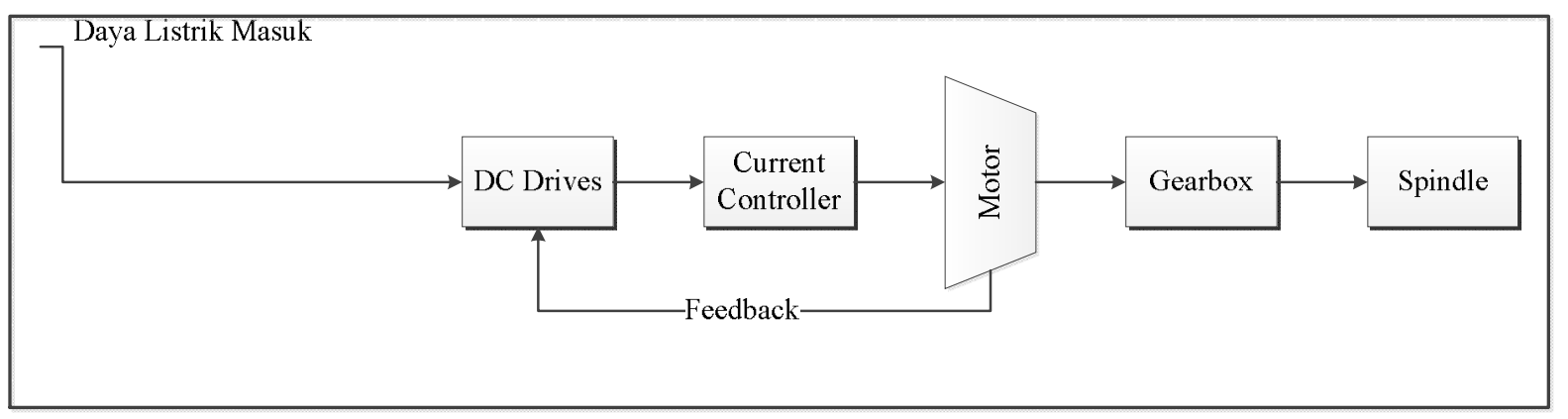

Gambar 9. Skema diagram sistem kendali motor spindle setelah retrofit

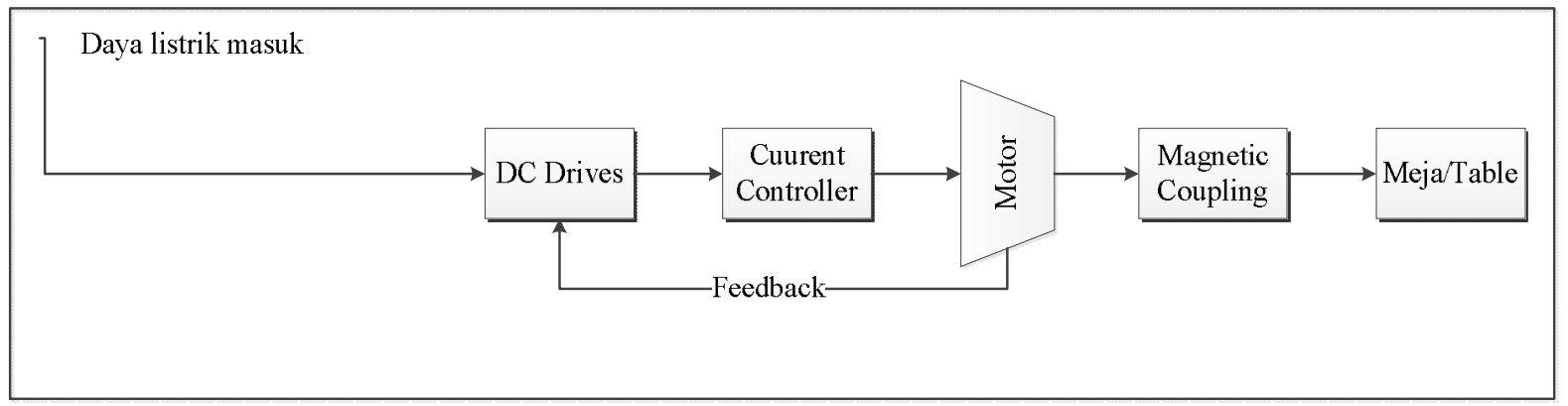

Gambar 10. Skema diagram sistem kendali motor axis setelah retrofit

Pada skema diagram sistem kendali motor spindle, listrik arus bolak balik yang masuk (power in) langsung terhubung ke drives kemudian diubah menjadi arus searah dan dihubungkan ke motor DC spindle. Pada motor spindle terdapat tacho generator yang berfungsi memberikan sinyal umpan balik/feedback kepada drives. Poros motor spindle terhubung dengan rangkaian gigi transmisi pada rumah roda gigi/gearbox. Proses retrofit sistem kendali pada motor axis seperti terlihat pada gambar 10 yaitu dengan menggunakan sistem variabel speed $\mathrm{DC}$ drives untuk menggantikan sistem lama yaitu sistem motor-generator operated drives. Pada sistem variabel speed DC drives tidak lagi menggunakan motor-generator sebagai sumber tenaga listrik untuk penggerak motor axis namun arus listrik tiga phase dari PLN diubah oleh DC drives menjadi arus searah DC sehingga dapat dihubungkan dengan motor axis yang merupakan motor DC servo.

Pengambilan data dilakukan sebanyak enam kali untuk mengetahui penggunaan daya listrik pada mesin horizontal boring \& milling setelah dilakukan proses retrofit sistem kelistrikan khususnya pada sistem kendali. Data yang didapat dapat dilihat pada gambar dibawah ini. 


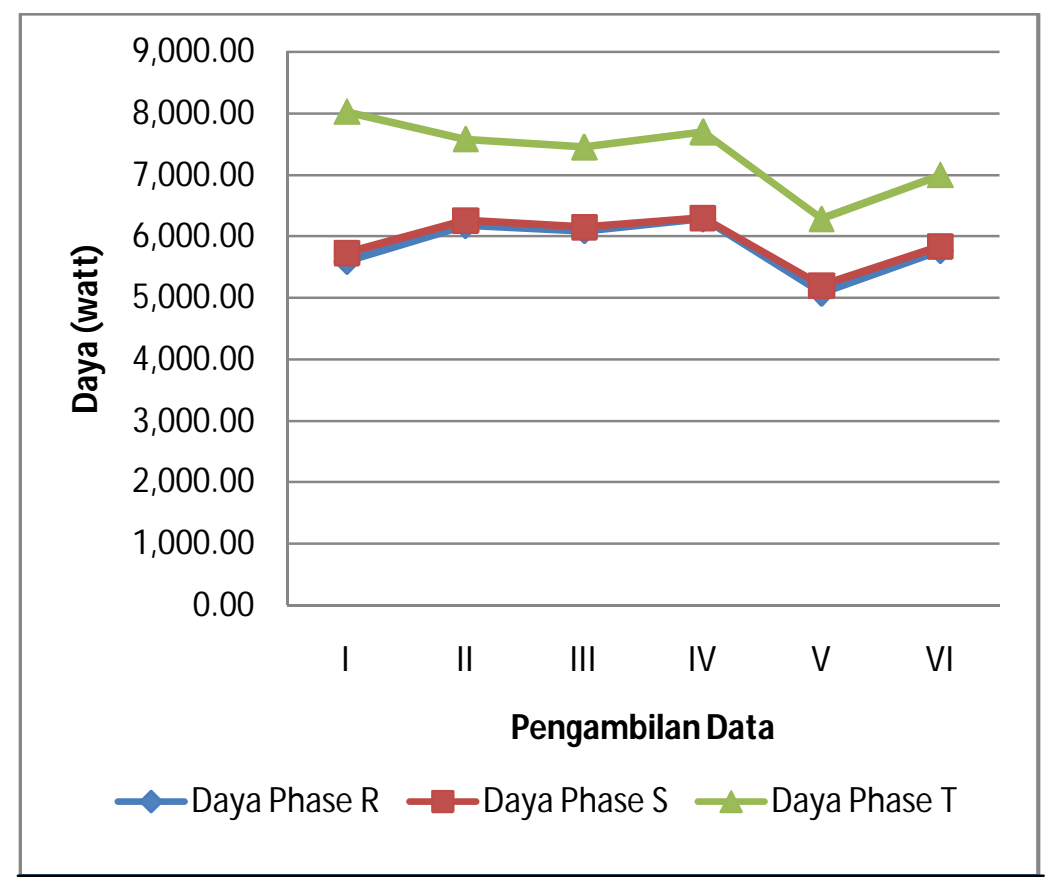

Gambar 11. Data konsumsi daya listrik setelah retrofit

\section{PEMBAHASAN}

Dari hasil pengambilan data penggunaan daya listrik pada mesin horizontal boring \& milling setelah dilakukan proses retrofit sistem kelistrikan khususnya sistem kendali motor spindle dan motor axis dapat dilihat adanya penurunan konsumsi daya listrik. Pengukuran yang dilakukan pada kondisi motor listrik yang bekerja yaitu motor spindle, motor axis $\mathrm{Z}$, motor hidrolik dan motor cooling fan untuk spindle, dengan kondisi yang sama, hasil pengukuran jumlah penggunaan daya listrik dapat dibandingkan. ${ }^{(6)}$

Di bawah ini ditampilkan gambar proses pemesinan pada mesin horizontal boring \& milling.

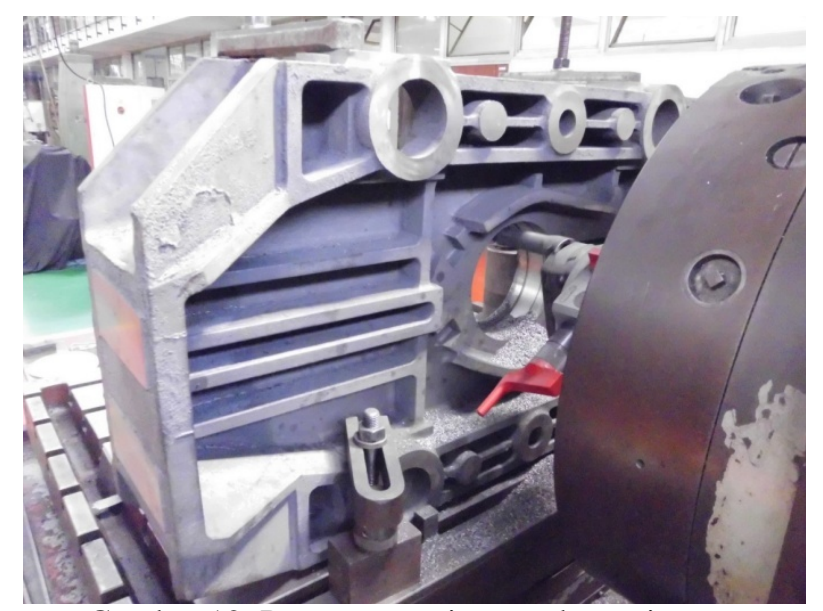

Gambar 12. Proses pemesinan pada mesin horizontal boring \& milling.
Dari hasil pengukuran terhadap konsumsi daya listrik setelah dilakukan retrofit sistem kelistrikan khususnya sistem kendali, didapat penurunan konsumsi daya listrik per phasa, hal ini diakibatkan dari perubahan sistem kendali yang asalnya dari sistem motorgenerator operated drives menjadi sistem variable speed DC drives. Dari hasil pengukuran konsumsi daya listrik per phase didapat prosentase penurunan konsumsi daya listrik dari setiap phase. Penurunan daya listrik setelah dilakukan proses retrofit sistem kendali yaitu untuk (1) phase $\mathrm{R}$ penurunannya sebesar $30 \%$; (2) phase S penurunan sebesar 29\% dan (3) phase $\mathrm{T}$ penurunan sebesar 19\%. Pada phase $\mathrm{T}$ penurunan daya listrik yang terjadi tidak sebesar pada phase $R$ maupun $S$ disebabkan adanya beberapa komponen listrik 1 phase yang terhubung ke phase $\mathrm{T}$. Komponen listrik 1 phase yang terhubung pada phase $\mathrm{T}$ yaitu diantaranya, sistem lampu penerangan mesin, transformator untuk sistem DC eksitasi motor servo spindle dan servo axis serta transformator untuk magnetic coupling. Rata-rata Penurunan konsumsi daya listrik setelah dilakukan proses retrofit pada sistem kelistrikan lama khususnya pada sistem kendali motor spindle dan motor axis yaitu sebesar 21,5\%. Hal ini sejalan dengan penelitian yang telah dilakukan oleh Bosch Rexroth yang menyatakan bahwa perubahan 
motor-generator operated drives dengan sistem variable speed $D C$ drives dapat menghemat energi hingga mencapai $50 \%$. $^{(7)}$

\section{KESIMPULAN DAN SARAN}

Dari penelitian mengenai efisiensi energi pada mesin horizontal boring \& milling yang terdapat di workshop pemesinan MIDC, dapat ditunjukan bahwa setelah dilakukan proses retrofit pada sistem kendali, dapat dicapai penurunan konsumsi daya listrik total sebesar $21,5 \%$.

\section{Ucapan Terima Kasih}

Penulis mengucapkan syukur alhamdulillah kepada Allah SWT. Ucapan terima kasih kepada bapak Agus Supriatna, yang telah membantu dalam proses pengumpulan data, bapak Ir. Hafid, MT. yang telah memberikan pengarahan pada saat penelitian, ibu Dewi Apriliani dan ibu Mila yang telah membantu pada saat penyusunan karya tulis ilmiah.
DAFTAR PUSTAKA

Bosch Rexroth AG. 2008. Energy Efficiency in Machine Tools.

Dietmair, A., Verla. 2009. Energy Consumption Forecasting and Optimization for Tool Machines, Modern Machines Science Journal.

F. Draganescu, M. Gheorghe, C.V. Doicin, 2002. Models of Machine Tools Efficiency and Specific Consumed Energy, Journal of Materials Processing Technology 141 (2003) 9-15.

Heidenhain. 2010. Aspect of Energy Efficiency in Machine Tools.

Pegard S.A.. 1973. Operation and Service Manual Book. Belgium.

S.K. Hajra Choudhury, A.K. Hajra Choudhury, Nirjhar Roy. 2006, Element of Workshop Technology Vol. II Machine Tools. Mumbai: Media Promoteurs \& Publishers.

Siemens. 2007. Simoreg DC-Master, Operation Instruction. 